\title{
Evaluation of the cellular antioxidant activity of 25 commonly consumed fruit species in China based on Caco-2 cells
}

\author{
Hongxia Wan ${ }^{1 \star \star}$, Renbin $\mathrm{Liu}^{2}$, Dong Liu ${ }^{1, \star \star \star}$, Haiyan Sun ${ }^{1}$, Xiangying Yu ${ }^{3}$, Yan $\mathrm{Li}^{1}$ and Yanli Cong ${ }^{1}$ \\ 1 Shenzhen Key Laboratory of Fermentation, Purification and Analysis, Shenzhen Polytechnic, Shenzhen 518055, People's Republic of China \\ 2 Department of Traditional Chinese Medical, Shiyan People's Hospital, Shiyan 442000, People's Republic of China \\ 3 State Key Laboratory of Chinese Medicine and Molecular Pharmacology, Shenzhen Research Institute of The Hong Kong Polytechnic \\ University, Shenzhen 518057, People's Republic of China
}

Received 18 March 2014 - Accepted 24 July 2014

\begin{abstract}
Introduction. Determination of antioxidant activity using a biological method is important in predicting antioxidant capacity in vivo. The Caco-2 cell-based antioxidant activity (CAA) assay quantifies antioxidant activity in Caco- 2 cells and has proved to possess good biological relevance. The aim of this study was to determine the CAA of 25 fruits commonly consumed in China, along with total phenolic content, total flavonoid content and oxygen radical absorbance capacity (ORAC). Materials and methods. The CAA was determined in Caco-2 cells by utilizing 2',7'-dichlorofluorescin diacetate (DCFH-DA) as a probe and 2,2'-azobis(2-methylpropionamidine) dihydrochloride (AAPH) as the generator of peroxyl radicals. The ORAC values were measured using fluorescein and AAPH. The total phenolic content was determined by the Folin-Ciocalteu method and total flavonoid content by aluminum chloridesodium nitrite method. Results and discussion. There was a large variation in CAA values among different fruit species with the highest value in pomegranate $\left(96.3 \pm 5.6 \mu \mathrm{mol}\right.$ quercetin equivalents $\left.(\mathrm{QE}) 100 \mathrm{~g}^{-1}\right)$ and the lowest value in papaya $\left(0.453 \pm 0.031 \mu \mathrm{mol}\right.$ QE $\left.100 \mathrm{~g}^{-1}\right)$. For melons (white muskmelon, hami melon and watermelon), pineapple, pitaya, nectarine and loquat, the CAA was too low to be measured. Data analysis showed that CAA values were significantly correlated to total phenolic content $\left(R^{2}=0.159, P<0.05\right)$, and not correlated with total flavonoid content $(R=0.003, P>0.05)$ or ORAC values $\left(R^{2}=0.123, P>0.05\right)$. Conclusion. Increasing the consumption of fruits, especially pomegranate, is an effective strategy to increase antioxidant intake, thus helpful for consumers to protect against the oxidative stressors.
\end{abstract}

Keywords: China / temperate and tropical fruits / biological antioxidants / phenolic compounds / oxygen radical absorbance capacity (ORAC)

Résumé - Évaluation de l'activité anti-oxydante cellulaire de 25 espèces de fruits généralement consommés en Chine basée sur des cellules Caco-2. Introduction. La détermination de l'activité anti-oxydante utilisant la méthode biologique présente un fort intérêt pour prévoir la capacité anti-oxydante in vivo. Le test d'activité anti-oxydante à base de cellules Caco-2 (CAA) quantifie l'activité anti-oxydante dans des cellules Caco-2 avec une bonne pertinence biologique. Le but de cette étude est de déterminer le CAA de 25 fruits généralement consommés en Chine, en parallèle avec leur teneur phénolique totale, leur contenu total en flavonoïdes et leur capacité d'absorbance des radicaux oxygénés (ORAC). Matériel et méthodes. Le CAA a été déterminé dans des cellules Caco-2 en utilisant la 2',7'dichlorofluorescéine diacétate (DCFH-DA) comme sonde et le 2,2'-azobis (2-methylpropionamidine) dihydrochloride (AAPH) comme générateur de radicaux peroxyl. Les valeurs d'ORAC ont été mesurées en utilisant la fluorescéine et l'AAPH. Le contenu phénolique total a été déterminé par la méthode de Folin-Ciocalteu et le contenu en flavonoïdes totaux par la méthode au chlorure d'aluminium et nitrite de sodium. Résultats et discussion. Nous avons observé une grande variation dans des valeurs de CAA parmi les diverses espèces de fruits, la valeur la plus haute pour la grenade (96,3 $\pm 5,6 \mu \mathrm{mol}$ d'équivalent quercétine (QE) pour $100 \mathrm{~g})$ et la valeur la plus basse pour la papaye $(0,453 \pm 0,031 \mu \mathrm{mol}$ QE $100 \mathrm{~g}^{-1}$ ). Les melons (cantaloup blanc, melon de Hami et pastèque), l'ananas, la pitaya, la nectarine et le néflier du Japon ont donné des valeurs de CAA trop faibles pour être mesurées. L'analyse des données a montré que les valeurs de CAA étaient significativement corrélées pour totaliser le contenu phénolique $\left(R^{2}=0,159, P<0,05\right)$,

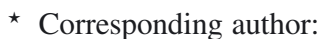

liudongsz@szpt.edu.cn, susan@szpt.edu.cn

$\star \star$ These authors contributed equally to this work
} 
et non corrélées avec le contenu en flavonoïdes totaux $(R=0,003, P<0,05)$ ou avec les valeurs d'ORAC $\left(R^{2}=0,123\right.$, $P>0,05)$. Conclusion. Augmenter la consommation de fruits des ménages, en particulier la grenade, peut être une stratégie payante pour augmenter l'absorption d'anti-oxydants, et ainsi rendre un service santé au consommateur par protection contre le stress oxydatif.

Mots clés : Chine / fruits tropicaux / anti-oxidants biologiques / composés phénoliques / capacité d'absorbance des radicaux oxygénés (ORAC)

\section{Introduction}

Reactive oxygen species (ROS) are reactive molecules generated in the body as a result of oxidative metabolism. The presence of excessive ROS, resulting from the imbalance between the production of ROS and the antioxidant defense system in the body, could lead to the development of several pathologies, such as cardiovascular disease, diabetes and cancer $[1,2]$. Numerous studies have shown that bioactive phytochemicals in fruits, such as flavonoids, phenolic acids and vitamins, possess strong antioxidant activity [3], and fruit consumption is nutritionally important to supply exogenous antioxidants to eliminate the excessive ROS in the body. Thus, diets rich in fruits could decrease the risk of diseases [4-6].

To be certain of the antioxidant potential of fruits and provide useful information for consumers to plan antioxidant diet against the oxidative stressors, several chemical antioxidant activity assays have been employed. These include the oxygen radical absorbance capacity (ORAC) assay, ferric reducing/antioxidant power (FRAP) assay, total radicaltrapping antioxidant parameter (TRAP) assay, total oxyradical scavenging capacity (TOSC) assay and ABTS radical scavenging activity assay [7-10]. Considering that the chemical assay is performed in a test tube under non-physiological conditions and do not consider the absorption and metabolism of the antioxidant compound [11], these results are questionable for predicting antioxdiant capactiy in vivo. Thus, it is important to evaluate the antioxidant potential of fruits using a biologically relevant assay. However, antioxidant assays using animals, despite providing a true reflection of the antioxidant capacity in vivo, possess the disadvantage of long operation time and great expense, which makes the assay unsuitable for the screening of fruits for health benefits. Hence, the cell-based assay as an intermediate testing method is attractive.

The cellular antioxidant activity assay based on HepG2 cell model was developed and employed to survey the antioxidant activity of commonly consumed fruits in America $[12,13]$. It showed that the result from no PBS (Phosphate-Buffered Saline) wash was more significantly correlated with ORAC values in vitro even though the result from PBS wash should more accurately reflect the antioxidant activity of antioxidants in vivo. Therefore, our laboratory established a new quantitative Caco-2 cell-based antioxidant activity assay (shown in another submitted manuscript) [14] based on the assumption that Caco-2 cellular model could reflect intestinal absorption characteristics of antioxidants before showing antioxidant effect in the body since good correlation was observed between the in vitro absorption in Caco-2 cellular model and in vivo intestinal absorption $[15,16]$. This assay was shown to possess good biological relevance by comparison with the results from animal experiments. It utilizes 2',7'-dichlorofluorescin diacetate (DCFH-DA) as a probe in cultured Caco-2 cells, which is deacetylated by cellular esterases to form polar 2', 7'-dichlorofluorescin (DCFH) and then fluoresces when oxidized by peroxyl radicals to dichlorofluorescein (DCF).

Since there was no report on the cellular antioxidant activity of fruits commonly consumed in China, and the Caco-2 cell-based antioxidant activity (CAA) assay proved to possess good biological relevance in our previous experiment, the objective of this study was to determine the Caco-2 cell-based antioxidant activity of 25 commonly consumed fruit species in China. The total phenolic content, total flavonoid content, and ORAC values of fruit species were also measured to further investigate the relationship between CAA values and ORAC values and total phenolic or flavonoid content. In this manuscript, we report for the first time CAA values for 25 fruit species commonly consumed in China, thus providing new information on the antioxidant function of fruits for nutritionists and the general public.

\section{Materials and methods}

\subsection{Chemicals}

Quercetin, gallic acid, (+)-catechin hydrate, fluorescein disodium salt, 6-hydroxy-2,5,7,8-tetramethylchroman-2carboxylic acid (Trolox), 2',7'-dichloro fluorescin diacetate (DCFH-DA), 4-(2-hydroxyethyl)-1-piperazineethane sulfonic acid (Hepes), 2,2'-azobis(2-methylpropionamidine)dihydrochloride (AAPH), non-essential amino acid $(100 \times)$, trypan blue solution $(0.4 \%)$, and dimethyl sulfoxide (DMSO) were purchased from Sigma-Aldrich, Inc. (St. Louis, MO). Caco-2 colon adenocarcinoma cells were obtained from the American Type Culture Collection (ATCC) (Rockville, MD). Williams' Medium E (WME), Dulbecco's Modified Eagle Medium (DMEM), fetal bovine serum (FBS), Hanks' Balanced Salt Solution (HBSS, $1 \times$ ), pen strep solution $(100 \times)$, and $0.05 \%$ Trypsin-EDTA were purchased from Gibco Life Technologies (Grand Island, NY). Other reagents were obtained from Damao chemical reagent factory of Tianjin (Tianjin, CN).

\subsection{Sample preparation}

Twenty-five fruit species were purchased from Buji Market (Shenzhen, Guangdong). They were harvested at 
the edible maturity stage from the main producing areas in China: apple (Malus pumila Mill.) (Yantai, Shangdong), apricot (Armeniaca vulgaris Lam.) (Kashgar, Xinjiang), banana (Musa nana Lour.) (Qinzhou, Guangxi), carambola (Averrhoa carambola L.) (Guangzhou, Guangdong), clausena lansium (Clausena lansium (Lour.) Skeels) (Zhanjiang, Guangdong), guava (Psidium guajava Linn.) (Taiwai), hami melon (Cucumis melo var. saccharinus) (Turpan, Xinjiang), kiwifruit (Actinidia Lindl.) (Baoji, Shanxi), litchi (Litchi chinensis Sonn.) (Gaozhou, Guangdong), longan (Dimocarpus longan Lour.) (Quanzhou, Fujian), loquat (Eriobotrya japonica Thunb. Lindl.) (Putian, Fujian), mango (Mangifera indica L.) (Lingshui, Hainan), nectarine (Prunus persica var. nectarine) (Shuanghe, Xinjiang), orange (Citrus sinensis) (Ganzhou, Jiangxi), papaya (Carica papaya L.) (Lingshui, Hainan), peach (Amygdalus persica L.) (Qinan, Gansu), pear (Pyrus sorotina) (Laiyang, Shangdong), pineapple (Ananas comosus (Linn.) Merr.) (Zhanjiang, Guangdong), pitaya (Hylocereus undulatus Britt.) (Qinzhou, Guangxi), plum (Prunus salicina Lindl.) (Guiding, Guizhou), pomegranate (Punica granatum L.) (Lintong, Shanxi), red grape (Vitis vinifera) (Turpan, Xinjiang), tangerine (Citrus reticulata) (Sihui, Guangdong), watermelon (Citrullus lanatus) (Guangshui, Guangdong), and white muskmelon (Cucumis melo) (Turpan, Xinjiang). Extracts were prepared from the edible part of fresh fruits according to the procedures described previously [17] with slight modifications. Briefly, in triplicate, $100 \mathrm{~g}$ fresh fruit weight from the edible part of fruits were homogenized with chilled $80 \%$ acetone $(1: 2, \mathrm{w} / \mathrm{v})$ using a chilled Philips blender for $3 \mathrm{~min}$. The sample was then further homogenized using an IKA homogenizer (T25 digital Ultra-Turrax, IKA Works, Inc., Staufen, Germany) for an additional $5 \mathrm{~min}$ in the ice bath. The homogenates were filtered through No.1 Whatman paper on a Buchner funnel under vacuum. The filtrate was collected, and in duplicate, the residue was homogenized with $200 \mathrm{~mL}$ of chilled $80 \%$ acetone using the homogenizer for $8 \mathrm{~min}$ in the ice bath. The filtration was also performed in duplicate. Three aliquots of filtrate were pooled and evaporated by a rotary evaporator under vacuum at $45{ }^{\circ} \mathrm{C}$ until approximately $90 \%$ of the filtrate had evaporated. The filtrate was then reconstituted in deionized water and kept frozen at $-80^{\circ} \mathrm{C}$ until analysis. Control extracts were prepared using the same extraction solvents and procedures but without fruits.

\subsection{Cell culture}

Caco- 2 cells were grown in growth medium (high glucose DMEM supplemented with $10 \%$ FBS, $10 \mathrm{mM}$ Hepes, $1 \%$ nonessential amino acid, 100 units $\mathrm{mL}^{-1}$ penicillin, $100 \mu \mathrm{g} \mathrm{mL}$ streptomycin) and were maintained at $37^{\circ} \mathrm{C}$ in $5 \% \mathrm{CO}_{2}$. Cells used in this study were between passages 10 and 30 .

\subsection{Cytotoxicity}

The cytotoxicity of fruits toward Caco-2 cells was measured using the colorimetric methylene blue assay reported previously [12]. Caco- 2 cells were seeded at $4 \times 10^{4}$ well $^{-1}$ on a 96-well microplate in $100 \mu \mathrm{L}$ of growth medium at $37^{\circ} \mathrm{C}$. Twenty-four hours after seeding, the growth medium was removed, and the cells were washed with $100 \mu \mathrm{L}$ of PBS. Then, $100 \mu \mathrm{L}$ of treatment medium (WME) supplemented with $2 \mathrm{mM}$ L-glutamine and $10 \mathrm{mM}$ Hepes) containing various concentrations of fruit extracts were applied to the cells, and the microplates were incubated at $37{ }^{\circ} \mathrm{C}$ for $24 \mathrm{~h}$. The treatment medium was removed, and the cells were washed with PBS. A volume of $50 \mu \mathrm{L}$ well ${ }^{-1}$ methylene blue staining solution (98\% HBSS, $0.67 \%$ glutaraldehyde, $0.6 \%$ methylene blue) was applied to each well, and the microplate was incubated at $37{ }^{\circ} \mathrm{C}$ for $1 \mathrm{~h}$. The dye was removed, and the plate was immersed in fresh deionized water until the water was clear. The water was tapped out of the wells, and the microplate was allowed to air-dry briefly before $100 \mu \mathrm{L}$ of elution solution (49\% PBS, $50 \%$ ethanol, $1 \%$ acetic acid) was added to each well. Then the microplate was placed on a bench-top shaker for $20 \mathrm{~min}$ to allow uniform elution. The absorbance was read at $570 \mathrm{~nm}$ with blank subtraction using the Spectra Max M2 spectrophotometer (MD, USA). The median cytotoxic concentration $\left(\mathrm{CC}_{50}\right)$ was calculated for each fruit.

\subsection{Caco-2 cell-based antioxidant activity (CAA) of fruit extracts}

The Caco-2 cell-based antioxidant activity of fruit extracts was determined using the protocol described previously [14]. Caco- 2 cells suspension were seeded at a density of $5 \times 10^{4}$ well $^{-1}$ on a black, clear-bottom, 96-well microplate in $100 \mu \mathrm{L}$ growth medium.well ${ }^{-1}$. Twenty-four hours after seeding, the growth medium was removed and the adherent cells were washed once with $150 \mu \mathrm{L} 1 \times$ PBS. Cells were then incubated for $20 \mathrm{~min}$ with $100 \mu \mathrm{L}$ antioxidant treatment medium (DMEM containing $10 \mathrm{mM}$ Hepes) containing control extracts, fruit extracts or quercetin of different concentrations plus $60 \mu \mathrm{M}$ DCFH-DA. Treatment medium was removed and the cells were washed once with $150 \mu \mathrm{L}$ PBS. Cells were then treated with $500 \mu \mathrm{M}$ AAPH in $100 \mu \mathrm{L}$ oxidant treatment medium (HBSS containing $10 \mathrm{mM}$ Hepes) except blank cells, which were treated with oxidant treatment medium containing no AAPH, and the microplate was placed into a Spectra Max M5e multifunctional plate reader (Molecular Devices, Sunnyvale, CA) at $37^{\circ} \mathrm{C}$. Fluorescence emitted at $538 \mathrm{~nm}$ with excitation at $485 \mathrm{~nm}$ was measured every $5 \mathrm{~min}$ for $90 \mathrm{~min}$. The area under the fluorescence versus time curve (AUC) was integrated to calculate the CAA values of fruits as reported previously [12]. CAA values for fruit extracts were expressed as micromoles of quercetin equivalents $(\mathrm{QE})$ per $100 \mathrm{~g}$ fresh fruit.

\subsection{Determination of total phenolic content}

The total phenolic contents of fruits were determined from their $80 \%$ acetone extracts by using a colorimetric FolinCiocalteu method reported previously [18] with slight modifications. Briefly, all fruit extracts were diluted five fold with deionized water to obtain readings within the standard curve 
ranges of $0.0 \sim 400.0 \mu \mathrm{g}$ gallic acid $\mathrm{mL}^{-1}$. Then $100 \mu \mathrm{L}$ of the standard gallic acid solution or diluted fruit extract was mixed with $0.4 \mathrm{~mL}$ of distilled water in a test tube, followed by the addition of $100 \mu \mathrm{L}$ of Folin-Ciocalteu reagent. After reaction for $6 \mathrm{~min}, 1 \mathrm{~mL}$ of a $7 \% \mathrm{Na}_{2} \mathrm{CO}_{3}$ solution was added and the final volume was adjusted to $2.4 \mathrm{~mL}$ with deionized water. Samples were allowed to stand for $90 \mathrm{~min}$ at room temperature before the absorbance was measured at $760 \mathrm{~nm}$ versus a blank using a Spectra Max M5e multifunctional plate reader. The results were reported as milligrams of gallic acid equivalents (GAE) per $100 \mathrm{~g}$ fresh fruit.

\subsection{Determination of total flavonoid content}

The total flavonoid content of fruits was measured from their $80 \%$ acetone extracts using a modified colorimetric method reported previously [19] with some modifications in this study. That is, fruit extracts were diluted appropriately with deionized water to obtain readings within the standard curve ranges of $0.0-80.0 \mu \mathrm{g}(+)$-catechin $\mathrm{mL}^{-1}$. Then $2 \mathrm{~mL}$ of the standard (+)-catechin solution or diluted fruit extract was reacted with $75 \mu \mathrm{L} \mathrm{NaNO}_{2}$ solution in a test tube for $6 \mathrm{~min}$, followed by the addition of $150 \mu \mathrm{L} 10 \% \mathrm{AlCl}_{3} \cdot 6 \mathrm{H}_{2} \mathrm{O}$ solution. The mixture was allowed to stand for another $5 \mathrm{~min}$ before the addition of $0.5 \mathrm{~mL}$ of $1 \mathrm{M} \mathrm{NaOH}$, and the total volume was adjusted to $2.5 \mathrm{~mL}$ with deionized water. The solution was mixed well and the absorbance was measured immediately at $510 \mathrm{~nm}$ using a Spectra Max M5e multifunctional plate reader. The results were presented as milligrams of catechin equivalents (CE) per $100 \mathrm{~g}$ fresh fruit.

\subsection{Determination of oxygen radical scavenging capacity (ORAC)}

The ORAC assay, with the procedures reported previously [20], was used to determine the total antioxidant activity of fruit extracts. Briefly, $20 \mu \mathrm{L}$ of blank, Trolox standard $(6.25,12.5,25$, and $50 \mu \mathrm{M})$, or fruit extracts in $75 \mathrm{mM}$ potassium phosphate buffer ( $\mathrm{pH} 7.4$ ), was added to triplicate wells in a black, clear-bottom, 96-well microplate. The outside wells were not used. A volume of $200 \mu \mathrm{L}$ of $0.96 \mu \mathrm{M}$ fluorescein in potassium phosphate buffer was added to each well and incubated at $37{ }^{\circ} \mathrm{C}$ for $20 \mathrm{~min}$. Then $20 \mu \mathrm{L}$ of $119 \mathrm{mM}$ AAPH (freshly prepared) in potassium phosphate buffer was added. The microplate was immediately placed into a Spectra Max M5e multifunctional plate reader at $37^{\circ} \mathrm{C}$. Fluorescence emitted at $538 \mathrm{~nm}$ with excitation at $485 \mathrm{~nm}$ was measured every $4.5 \mathrm{~min}$ for $2.5 \mathrm{~h}$. The area under the fluorescence versus time curve (AUC) was integrated to calculate the ORAC values, which were expressed as micromoles of Trolox equivalents (TE) per $100 \mathrm{~g}$ fresh fruit.

\subsection{Statistical analysis}

All data were shown as mean \pm SD for triplicate data from the same treatment. Statistical analysis was performed using
SPSS V11.0 software (SPSS Inc, Chicago). Differences between means were performed by one-way ANOVA test using Duncan method as post hoc test. Pearson correlations between CAA values and ORAC values, total phenolics or total flavonoids were analyzed using bivariate correlation analysis. Significance was determined at $P<0.05$.

\section{Results}

\subsection{Total phenolic content}

The results obtained for total phenolic content of 25 fruit species are shown in figure 1. Among all the fruits analyzed, plum had the highest total phenolic content $(294 \pm 25 \mathrm{mg}$ GAE $100 \mathrm{~g}^{-1}$ ), followed by pomegranate and clausena lansium $\left(240 \pm 20\right.$ and $239 \pm 11 \mathrm{mg} \mathrm{GAE} 100 \mathrm{~g}^{-1}$, respectively); guava $\left(208 \pm 10 \mathrm{mg}\right.$ GAE $\left.100 \mathrm{~g}^{-1}\right)$; red grape $(181 \pm 12 \mathrm{mg}$ GAE $\left.100 \mathrm{~g}^{-1}\right)$; carambola $\left(138 \pm 11 \mathrm{mg}\right.$ GAE $\left.100 \mathrm{~g}^{-1}\right)$; apple, litchi and apricot $(115 \pm 6,108 \pm 7$, and $96.8 \pm 2.2 \mathrm{mg}$ GAE $100 \mathrm{~g}^{-1}$, respectively). The total phenolic content of tangerine $\left(92.5 \pm 1.6 \mathrm{mg}\right.$ GAE $\left.100 \mathrm{~g}^{-1}\right)$ was not significantly different from that of litchi and apricot, and the value for orange and loquat $\left(87.7 \pm 1.6\right.$ and $83.7 \pm 8.3 \mathrm{mg} \mathrm{GAE} 100 \mathrm{~g} \mathrm{~g}^{-1}$, respectively) were not significantly different from those of apricot and tangerine. The value of total phenolic content of kiwifruit $\left(68.8 \pm 2.8 \mathrm{mg}\right.$ GAE $\left.100 \mathrm{~g}^{-1}\right)$ was not significantly different from those observed for longan $(67 \pm 6 \mathrm{mg}$ GAE $\left.100 \mathrm{~g}^{-1}\right)$. Also similar were pear and papaya $(44.6 \pm 4.3$ and $43.8 \pm 1.1 \mathrm{mg} \mathrm{GAE} 100 \mathrm{~g}^{-1}$, respectively), and pineapple and peach $\left(40.9 \pm 1.2\right.$ and $38.6 \pm 0.9 \mathrm{mg} \mathrm{GAE} 100 \mathrm{~g}^{-1}$, respectively). The ranking order of total phenolic content in the remaining fruit species was as follows: banana $(31.4 \pm 2.5 \mathrm{mg}$ GAE $\left.100 \mathrm{~g}^{-1}\right)$, nectarine $\left(30.1 \pm 2.8 \mathrm{mg}\right.$ GAE $\left.100 \mathrm{~g}^{-1}\right)$, mango $\left(28.9 \pm 1.3 \mathrm{mg} \mathrm{GAE} 100 \mathrm{~g}^{-1}\right)$, pitaya $(25.4 \pm 0.8 \mathrm{mg}$ GAE $\left.100 \mathrm{~g}^{-1}\right)$, white muskmelon $\left(19 \pm 1.7 \mathrm{mg} \mathrm{GAE} 100 \mathrm{~g}^{-1}\right)$, watermelon $\left(14.2 \pm 0.4 \mathrm{mg}\right.$ GAE $\left.100 \mathrm{~g}^{-1}\right)$, hami melon $\left(13.5 \pm 0.1 \mathrm{mg} \mathrm{GAE} 100 \mathrm{~g}^{-1}\right)$.

\subsection{Total flavonoid content}

As seen from figure 2, total flavonoid content varied within a wide range of values, with the highest total flavonoid value in plum $\left(1248 \pm 62 \mathrm{mg} \mathrm{CE} 100 \mathrm{~g}^{-1}\right)$ and the lowest in papaya $\left(2.45 \pm 0.22 \mathrm{mg} \mathrm{CE} 100 \mathrm{~g}^{-1}\right)$. Among other fruits, red grape had the second highest flavonoid content $\left(897 \pm 83 \mathrm{mg} \mathrm{CE} 100 \mathrm{~g}^{-1}\right)$, followed by carambola

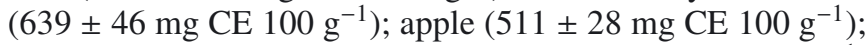
litchi and loquat $\left(454 \pm 35\right.$ and $442 \pm 47 \mathrm{mg} \mathrm{CE} 100 \mathrm{~g}^{-1}$, respectively); apricot $\left(356 \pm 8 \mathrm{mg} \mathrm{CE} 100 \mathrm{~g}^{-1}\right)$; guava $\left(284 \pm 30 \mathrm{mg} \mathrm{CE} 100 \mathrm{~g}^{-1}\right)$; clausena lansium and pomegranate $\left(226 \pm 27\right.$ and $223 \pm 16 \mathrm{mg} \mathrm{CE} 100 \mathrm{~g}^{-1}$, respectively); peach $\left(187 \pm 13 \mathrm{mg} \mathrm{CE} 100 \mathrm{~g}^{-1}\right)$ and pear $(157 \pm 10 \mathrm{mg}$ CE $\left.100 \mathrm{~g}^{-1}\right)$. There was no significant difference in total flavonoids between peach and clausena lansium, pomegranate or pear. The other fruits had the relatively low total flavonoids 


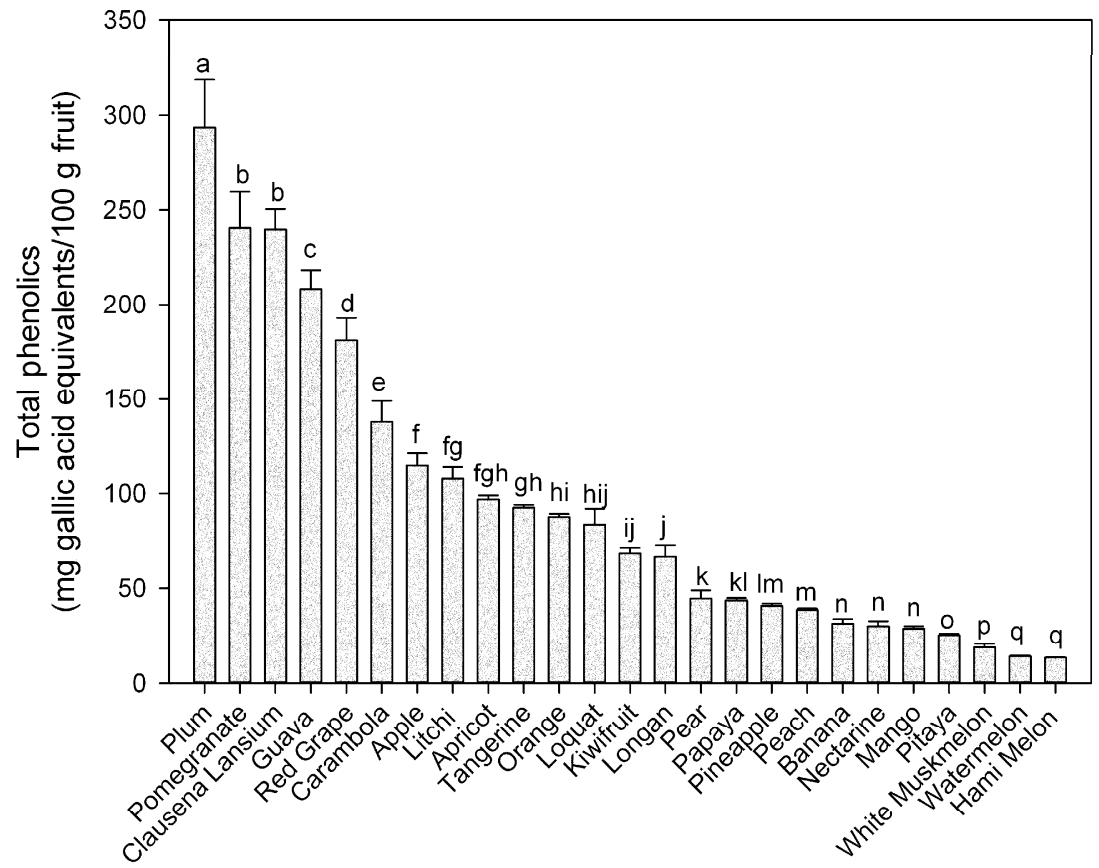

Figure 1. Total phenolic content of selected fruit species (mean $\pm \mathrm{SD}, n=3$ ). Bars with no letters in common are significantly different $(P<0.05) . \mathrm{SD}=$ standard deviation.

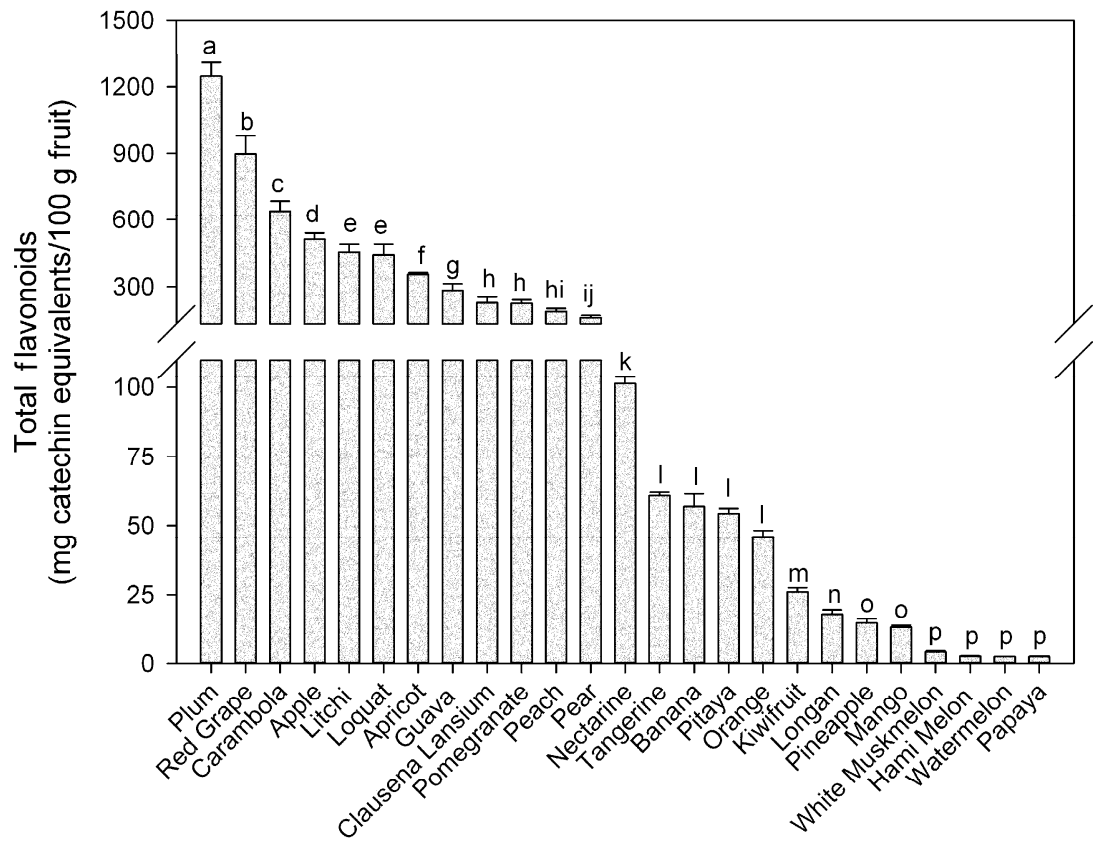

Figure 2. Total flavonoid content of selected fruit species (mean $\pm \mathrm{SD}, n=3$ ). Bars with no letters in common are significantly different $(P<0.05) . \mathrm{SD}=$ standard deviation.

with the decreasing order as follows: nectarine $(101 \pm 2 \mathrm{mg}$ CE $\left.100 \mathrm{~g}^{-1}\right)$, tangerine $\left(60.8 \pm 1.3 \mathrm{mg} \mathrm{CE} 100 \mathrm{~g}^{-1}\right)$, banana $\left(56.9 \pm 4.7 \mathrm{mg} \mathrm{CE} 100 \mathrm{~g}^{-1}\right)$, pitaya $(54.3 \pm 1.9 \mathrm{mg}$ CE $\left.100 \mathrm{~g}^{-1}\right)$, orange $\left(45.8 \pm 2.3 \mathrm{mg} \mathrm{CE} 100 \mathrm{~g}^{-1}\right)$, kiwifruit

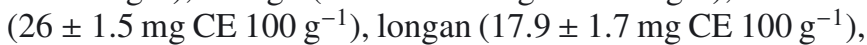
pineapple $\left(14.7 \pm 1.5 \mathrm{mg} \mathrm{CE} 100 \mathrm{~g}^{-1}\right)$, mango $(13.1 \pm 0.7 \mathrm{mg}$

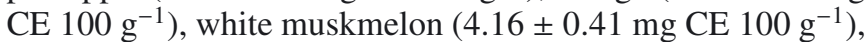
hami melon $\left(2.59 \pm 0.22 \mathrm{mg} \mathrm{CE} 100 \mathrm{~g}^{-1}\right)$, watermelon $\left(2.46 \pm 0.09 \mathrm{mg}\right.$ CE $\left.100 \mathrm{~g}^{-1}\right)$, papaya $(2.45 \pm 0.22 \mathrm{mg}$ CE $\left.100 \mathrm{~g}^{-1}\right)$.

\subsection{Oxygen radical scavenging capacity (ORAC)}

The ORAC values of fruit species tested varied widely, ranging from 197 to 4,040 $\mu \mathrm{mol} \mathrm{TE} 100 \mathrm{~g}^{-1}$ (figure 3). Of all the selected fruit species, plum had the highest ORAC 


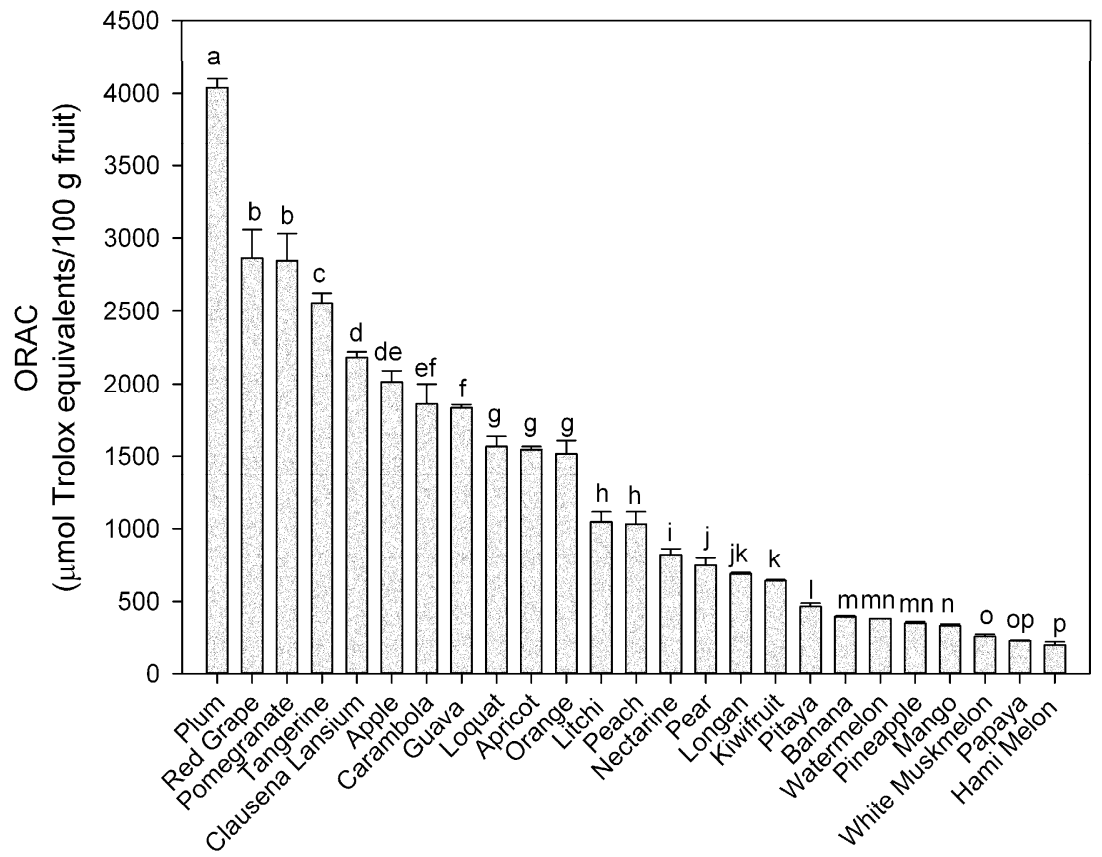

Figure 3. ORAC values of selected fruit species (mean $\pm \mathrm{SD}, n=3)$. Bars with no letters in common are significantly different $(P<0.05)$. $\mathrm{SD}=$ standard deviation .

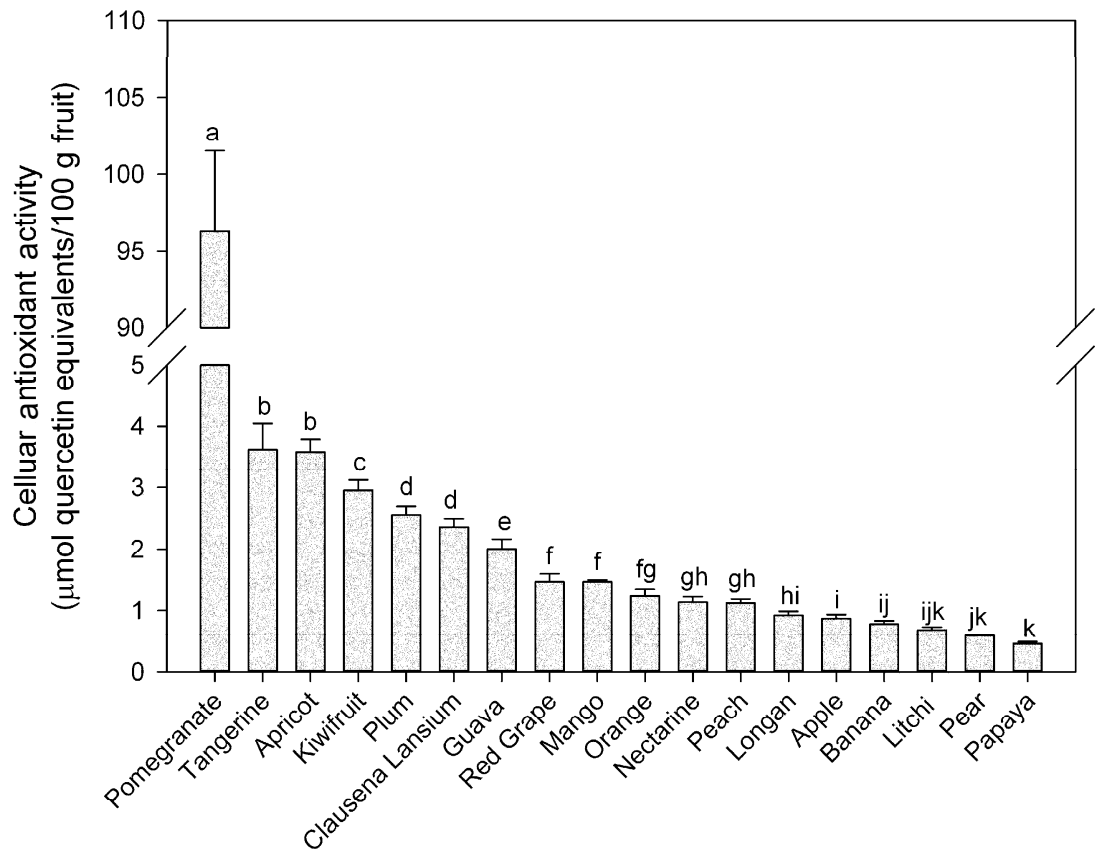

Figure 4. CAA values of quantifiable fruit species (mean $\pm \mathrm{SD}, n=3)$. Bars with no letters in common are significantly different $(P<0.05)$. $\mathrm{SD}=$ standard deviation .

value $\left(4,040 \pm 61 \mu \mathrm{mol}\right.$ TE $\left.100 \mathrm{~g}^{-1}\right)$, followed by red grape and pomegranate $(2,865 \pm 193$ and $2,846 \pm 185 \mu \mathrm{mol}$ TE $100 \mathrm{~g}^{-1}$, respectively); and tangerine $(2,557 \pm 69 \mu \mathrm{mol}$ TE $\left.100 \mathrm{~g}^{-1}\right)$. The ORAC value of apple $(2,016 \pm 77 \mu \mathrm{mol}$ TE $100 \mathrm{~g}^{-1}$ ) was not significantly different from that of clausena lansium $\left(2,184 \pm 37 \mu \mathrm{mol}\right.$ TE $\left.100 \mathrm{~g}^{-1}\right)$ and carambola $\left(1,861 \pm 138 \mu \mathrm{mol} \mathrm{TE} 100 \mathrm{~g}^{-1}\right)$, which was significantly similar to that of guava $\left(1,834 \pm 22 \mu \mathrm{mol}\right.$ TE $\left.100 \mathrm{~g}^{-1}\right)$. Other fruits in order of ORAC values were loquat, apricot and orange $\left(1,566 \pm 72,1,545 \pm 22\right.$ and 1,517 $\pm 91 \mu \mathrm{mol} \mathrm{TE} 100 \mathrm{~g}^{-1}$, respectively); litchi and peach $(1,046 \pm 70$ and 1,030 $\pm 86 \mu \mathrm{mol}$ TE $100 \mathrm{~g}^{-1}$, respectively); nectarine (822 $\pm 41 \mu \mathrm{mol}$ TE $\left.100 \mathrm{~g}^{-1}\right)$; pear $\left(747 \pm 49 \mu\right.$ mol TE $\left.100 \mathrm{~g}^{-1}\right)$; longan $\left(690 \pm 7 \mu\right.$ mol TE $\left.100 \mathrm{~g}^{-1}\right)$; kiwifruit $(641 \pm 6 \mu \mathrm{mol}$ TE $\left.100 \mathrm{~g}^{-1}\right)$; pitaya $\left(465 \pm 23 \mu \mathrm{mol}\right.$ TE $\left.100 \mathrm{~g}^{-1}\right)$; banana $\left(397 \pm 5 \mu \mathrm{mol}\right.$ TE $\left.100 \mathrm{~g}^{-1}\right)$; watermelon $(383 \pm 1 \mu \mathrm{mol}$ 


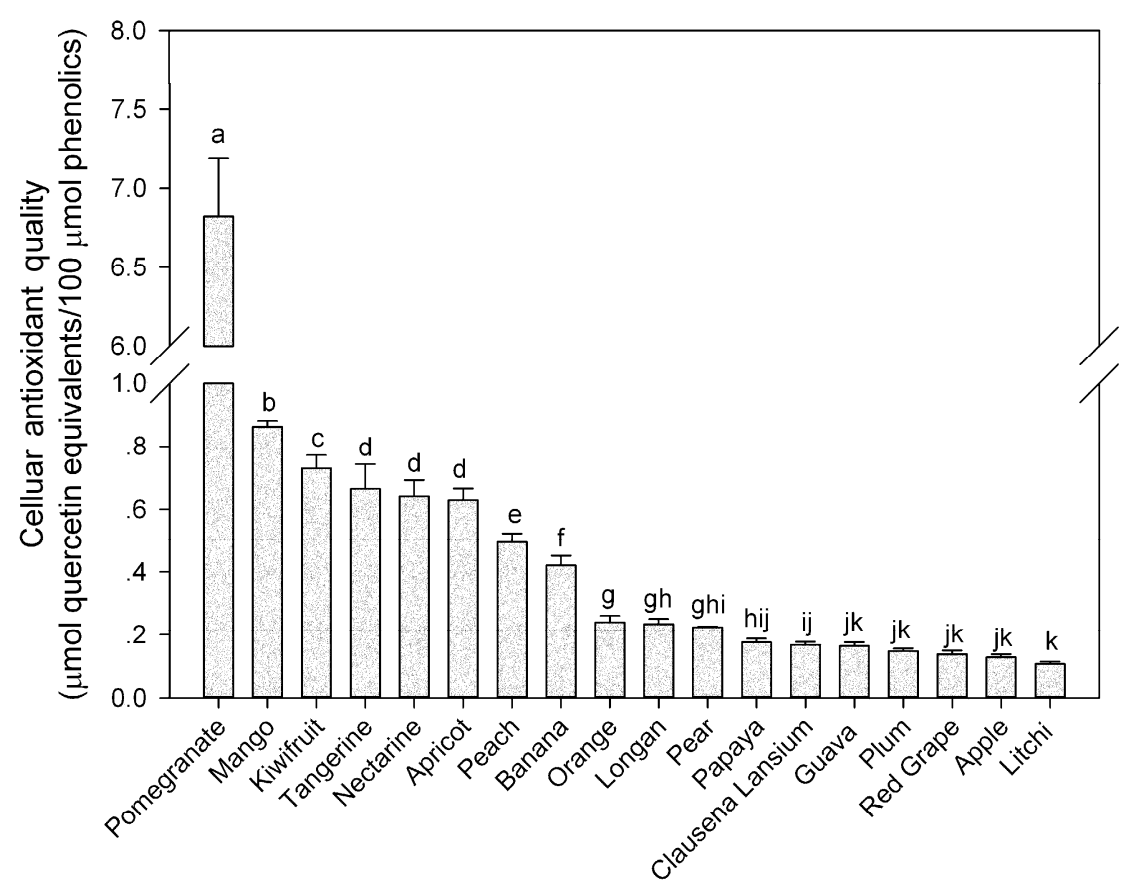

Figure 5. Caco-2 cell-based antioxidant quality of 18 fruit phenols in the Caco-2 cell-based antioxidant activity assay (mean $\pm \mathrm{SD}, n=3$ ). Bars with no letters in common are significantly different $(P<0.05)$. SD $=$ standard deviation.

TE $\left.100 \mathrm{~g}^{-1}\right)$; pineapple $\left(353 \pm 11 \mu\right.$ mol TE $\left.100 \mathrm{~g}^{-1}\right)$; mango $\left(335 \pm 11 \mu \mathrm{mol}\right.$ TE $\left.100 \mathrm{~g}^{-1}\right)$; white muskmelon $\left(262 \pm 16 \mu \mathrm{mol} \mathrm{TE} 100 \mathrm{~g}^{-1}\right)$; papaya $(227 \pm 10 \mu \mathrm{mol}$ TE $\left.100 \mathrm{~g}^{-1}\right)$ and hami melon $\left(197 \pm 23 \mu \mathrm{mol}\right.$ TE $\left.100 \mathrm{~g}^{-1}\right)$.

\subsection{Caco-2 cell-based antioxidant activity (CAA)}

CAA values of quantifiable fruits were shown in figure 4. A much higher CAA value was recorded in pomegranate $\left(96.3 \pm 5.6 \mu \mathrm{mol}\right.$ of $\left.\mathrm{QE} 100 \mathrm{~g}^{-1}\right)$. The other fruits detected had the CAA values of less than $4 \mu \mathrm{mol}$ QE $100 \mathrm{~g}^{-1}$ with the following order: tangerine and apricot $(3.62 \pm 0.43$ and $3.58 \pm 0.21 \mu \mathrm{mol}$ QE $100 \mathrm{~g}^{-1}$, respectively); kiwifruit $\left(2.95 \pm 0.17 \mu \mathrm{mol}\right.$ QE $\left.100 \mathrm{~g}^{-1}\right)$; plum and clausena lansium $\left(2.55 \pm 0.14\right.$ and $2.36 \pm 0.13 \mu \mathrm{mol}$ QE $100 \mathrm{~g}^{-1}$, respectively); guava $\left(2.01 \pm 0.16 \mu \mathrm{mol} \mathrm{QE} 100 \mathrm{~g}^{-1}\right)$; red grape and mango $\left(1.46 \pm 0.13\right.$ and $1.46 \pm 0.03 \mu \mathrm{mol}$ QE $100 \mathrm{~g}^{-1}$, respectively); orange $\left(1.24 \pm 0.11 \mu \mathrm{mol}\right.$ QE $\left.100 \mathrm{~g}^{-1}\right)$; nectarine and peach $\left(1.13 \pm 0.09\right.$ and $1.12 \pm 0.06 \mu \mathrm{mol} \mathrm{QE} 100 \mathrm{~g}^{-1}$, respectively); longan $\left(0.924 \pm 0.064 \mu \mathrm{mol}\right.$ QE $\left.100 \mathrm{~g}^{-1}\right)$; apple $\left(0.868 \pm 0.065 \mu \mathrm{mol}\right.$ of $\left.\mathrm{QE} \cdot 100 \mathrm{~g}^{-1}\right)$; bananas $\left(0.777 \pm 0.056 \mu \mathrm{mol}\right.$ QE $\left.100 \mathrm{~g}^{-1}\right)$; litchi $(0.680 \pm 0.049 \mu \mathrm{mol}$ QE $\left.100 \mathrm{~g}^{-1}\right)$; pear $\left(0.589 \pm 0.006 \mu \mathrm{mol}\right.$ QE $\left.100 \mathrm{~g}^{-1}\right)$; and papaya $\left(0.453 \pm 0.031 \mu \mathrm{mol} \mathrm{QE} 100 \mathrm{~g}^{-1}\right)$. For the other fruits (carambola, hami melon, loquat, pineapple, pitaya, watermelon and white muskmelon), the Caco-2 cell-based antioxidant activity was too low to be quantified. The cellular antioxidant activity of pineapple, watermelon, honeydew and cantaloupe was also unquantifiable in $\mathrm{HepG} 2$ cells due to their low activity [13]. In addition, the cytotoxicity of fruits toward Caco-2 cells could be ignored for all tested concentrations in
CAA assay since the cytotoxicity test showed that the fruits were of too low cytotoxicity.

\subsection{Correlation analysis}

The relationship between phytochemical contents (total phenolics and total flavonoids), ORAC values and CAA values for selected fruits were analyzed using bivariate correlation analysis. CAA values were positively correlated to total phenolic content despite the low correlation coefficient $\left(R^{2}=0.159, P<0.05\right)$ but showed no significant correlation with total flavonoids $(R=0.003, P>0.05)$ or ORAC values $\left(R^{2}=0.123, P>0.05\right)$.

\subsection{Caco-2 cell-based antioxidant quality}

The Caco-2 cell-based antioxidant quality of fruits ( $f i g$ ure 5) was calculated from their CAA values and total phenolic content, and expressed as mean \pm SD micromoles of quercetin equivalents (QE) per $100 \mu \mathrm{mol}$ of phenolic compounds. The highest Caco-2 cell-based antioxidant quality was recorded in pomegranate $\left(6.82 \pm 0.40 \mu \mathrm{mol} \mathrm{QE} 100 \mu \mathrm{mol}^{-1}\right)$, which was followed by mango $\left(0.862 \pm 0.019 \mu \mathrm{mol} \mathrm{QE} 100 \mu \mathrm{mol}^{-1}\right)$; kiwifruit $\left(0.730 \pm 0.041 \mu \mathrm{mol} \mathrm{QE} 100 \mu \mathrm{mol}^{-1}\right)$; tangerine, nectarine and apricot $(0.665 \pm 0.079,0.641 \pm 0.051$ and $0.629 \pm 0.037 \mu \mathrm{mol}$ QE $100 \mu \mathrm{mol}^{-1}$, respectively); peach $\left(0.495 \pm 0.028 \mu \mathrm{mol}\right.$ QE $\left.100 \mu \mathrm{mol}^{-1}\right)$; banana $(0.421 \pm 0.031$ of $\mu \mathrm{mol}$ QE $\left.100 \mu \mathrm{mol}^{-1}\right)$; orange $(0.240 \pm 0.021 \mu \mathrm{mol}$ QE $\left.100 \mu \mathrm{mol}^{-1}\right)$, longan $(0.235 \quad \pm 0.016 \mu \mathrm{mol}$ QE $\left.100 \mu \mathrm{mol}^{-1}\right)$; pear $\left(0.224 \pm 0.002 \mu \mathrm{mol}\right.$ QE $\left.100 \mu \mathrm{mol}^{-1}\right)$; papaya $\left(0.176 \pm 0.012 \mu \mathrm{mol} \mathrm{QE} 100 \mu \mathrm{mol}^{-1}\right)$; clausena 
lansium $\left(0.168 \quad \pm \quad 0.009 \quad \mu \mathrm{mol} \quad\right.$ QE $\left.100 \quad \mu \mathrm{mol}^{-1}\right)$; guava $\left(0.164 \pm 0.013 \mu \mathrm{mol} \quad \mathrm{QE} 100 \mu \mathrm{mol}^{-1}\right)$, plum $\left(0.148 \pm 0.008 \quad \mu \mathrm{mol}\right.$ QE $\left.100 \mu \mathrm{mol}^{-1}\right)$, red grape $\left(0.138 \pm 0.012 \mu \mathrm{mol} \quad \mathrm{QE} 100 \mu \mathrm{mol}^{-1}\right)$, apple $\left(0.128 \pm 0.010 \mu \mathrm{mol}\right.$ QE $\left.100 \mu \mathrm{mol}^{-1}\right)$ and litchi $\left(0.107 \pm 0.008 \mu \mathrm{mol}\right.$ QE $\left.100 \mu \mathrm{mol}^{-1}\right)$. The much higher cellular antioxidant quality of pomegranate phenols than other fruit phenols was also observed in HepG2 cell models [13].

\section{Discussion}

The Caco-2 cell-based antioxidant activity (CAA) assay has been developed in our laboratory to quantify antioxidant activity of phytochemicals in Caco- 2 cells, which are derived from human colon adenocarcinoma cells and have similar characteristics (such as morphology, marker enzyme, microvillar structure, tight junction and permeability) as small intestinal epithelial cells. That is, the CAA assay developed takes into consideration absorption characteristics of bioactive compounds in intestines. Thus, the CAA assay has good biological relevance.

In the present study, 25 commonly consumed fruit species in China were evaluated for their Caco- 2 cell-based antioxidant activity. Phytochemical contents (total phenolics and total flavonoids) and ORAC values for selected fruits were also measured and compared with CAA values. The total phenolic content of plum and apple agreed well with the values in a previous report [21], as was the case for red grape and pineapple [8]; apricot and kiwifruit [22,23]; guava, orange, pear, papaya, pitaya and white muskmelon [24]; and watermelon [13]. Besides, the high total phenolic content of plum among fruits, as well as the low total phenolic content of melons (cantaloupe melon, honeydew melon, white muskmelon, watermelon) in fruits, were also observed in other studies [13, 22, 23, 25, 26]. For the similar fruits investigated, the ranking order of total flavonoids corresponded well with the results obtained by Chun et al. [23] with the exception of grape and peach. The highest ORAC value in plum and red grape among tested fruit species, as well as the lowest ORAC value in melons, papaya and mango, was also reported by other authors $[13,25,26]$. Of the fruit species tested, pomegranate possessed much higher activity than other species in CAA assay, which was also observed in HepG2 cell-based antioxidant activity assay [13]. The high antioxidant activity of pomegranate among fruits was also demonstrated in FRAP assay [27]. Plum, being highest in total phenolic content, total flavonoid content and ORAC values among tested fruit species, ranked 5th in the CAA assay. Plum also showed high antioxidant activity in other chemical antioxidant assays, such as FRAP, TEAC, TRAP, ABTS and DPPH assay $[9,22-24,28,29]$, which might be attributed to the high content of anthocyanins [30]. For melons (white muskmelon, hami melon and watermelon), the Caco-2 cellbased antioxidant activity was too low to be detected, consistent with their low total phenolic content, total flavonoid content and ORAC values. This observation agrees with the literature showing that melons show low antioxidant activity among fruits using the FRAP, TRAP, ABTS and DPPH assays $[9,23,24,28,29]$. The low activity of papaya and pineapple might be due to high content of ascorbic acid in their extracts $[25,31]$, which showed low CAA value in our previous experiment.

Considering that the correlation coefficient between CAA values and total phenolic content was so small $\left(R^{2}=0.159\right)$, that is, the relation between CAA values and total phenolic content was weak, an objective index of antioxidant quality, a measure of the Caco-2 cell-based antioxidant activity provided by $100 \mu \mathrm{mol}$ phenolics in fruits, was used in this study to assess the relative potency of the antioxidants present in fruit. Pomegranate phenols proved to possess much higher antioxidant quality than other fruit phenols, which was also observed in cellular antioxidant quality based on HepG2 cell models [13], suggesting the high antioxidant potency of phenols in pomegranate. Thus, the high total phenolic content in pomegranate as well as high antioxidant potency of pomegranate phenols endowed the pomegranate with very high CAA values. Plum phenols were of low antioxidant quality, implying the low antioxidant potency of phenols in plum. Therefore, it was not surprising that plum was of moderate CAA value despite its high total phenolic content.

\section{Conclusion}

In summary, for the first time 25 commonly consumed fruit species in China were evaluated for their Caco-2 cell-based antioxidant activity. Among them, 18 fruits showed quantifiable CAA values within a wide range of values, the highest value being found in pomegranate $\left(96.3 \pm 5.6 \mu \mathrm{mol}\right.$ QE $\left.100 \mathrm{~g}^{-1}\right)$ and the lowest in papaya $\left(0.453 \pm 0.031 \mu \mathrm{mol}\right.$ QE $\left.100 \mathrm{~g}^{-1}\right)$. Melons (white muskmelon, hami melon and watermelon), pineapple, pitaya, nectarine and loquat had antioxidant activity too low to be measured by this method. A positive correlation was found between CAA values and total phenolic content. Determination of Caco-2 cell-based antioxidant activity of fruit is important in screening of fruits for potential health benefits based on the good biological relevance of the CAA assay. Thus, the data present in this study could be useful for consumers to plan antioxidant rich diets and for nutritionists to estimate health benefits of fruits from daily intake.

Acknowledgements. We are grateful for the financial support from Guangdong Natural Science Foundation (No. S2011010004455), Shenzhen Science and Technology Plan Project (No. JC201005280530A, JCYJ20130331151222011) and GDHVPS (2011).

\section{References}

[1] Stohs S.J., The role of free radicals in toxicity and disease, J. Basic Clin. Physiol. Pharmacol. 6 (1995) 205-228.

[2] Aruoma O., Free radicals, oxidative stress, and antioxidants in human health and disease, J. Amer. Oil. Chem. Soc. 75 (1998) 199-212.

[3] Prior R.L.,Cao G., Antioxidant phytochemicals in fruits and vegetables: Diet and health implications, HortScience 35 (2000) 588-592.

[4] Block G., Patterson B., Subar A., Fruit, vegetables, and cancer prevention: A review of the epidemiological evidence, Nutr. Cancer 18 (1992) 1-29. 
[5] Kelemen L.E., Cerhan J.R., Lim U., Davis S., Cozen W., Schenk M., Colt J., Hartge P., Ward M.H., Vegetables, fruit, and antioxidant-related nutrients and risk of non-hodgkin lymphoma: A national cancer institute-surveillance, epidemiology, and end results population-based case-control study, Am. J. Clin. Nutr. 83 (2006) 1401-1410.

[6] Hung H.-C., Joshipura K.J., Jiang R., Hu F.B., Hunter D., Smith-Warner S.A., Colditz G.A., Rosner B., Spiegelman D., Willett W.C., Fruit and vegetable intake and risk of major chronic disease, J. Natl. Cancer Inst. 96 (2004) 1577-1584.

[7] Proteggente A.R., Pannala A.S., Paganga G., Van Buren L., Wagner E., Wiseman S., Van De Put F., Dacombe C., RiceEvans C.A., The antioxidant activity of regularly consumed fruit and vegetables reflects their phenolic and vitamin $\mathrm{C}$ composition, Free Radical Res. 36 (2002) 217-233.

[8] Sun J., Chu Y.F., Wu X.Z., Liu R.H., Antioxidant and anti proliferative activities of common fruits, J. Agric. Food Chem. 50 (2002) 7449-7454.

[9] Pellegrini N., Serafini M., Colombi B., Del Rio D., Salvatore S., Bianchi M., Brighenti F., Total antioxidant capacity of plant foods, beverages and oils consumed in italy assessed by three different in vitro assays, J. Nutr. 133 (2003) 2812-2819.

[10] Wang H., Cao G., Prior R.L., Total antioxidant capacity of fruits, J. Agric. Food Chem. 44 (1996) 701-705.

[11] Frankel E.N., Meyer A.S., The problems of using onedimensional methods to evaluate multifunctional food and biological antioxidants, J. Sci. Food Agric. 80 (2000) 1925-1941.

[12] Wolfe K.L.,Liu R.H., Cellular antioxidant activity (caa) assay for assessing antioxidants, foods, and dietary supplements, J. Agric. Food Chem. 55 (2007) 8896-8907.

[13] Wolfe K.L., Kang X., He X., Dong M., Zhang Q., Liu R.H., Cellular antioxidant activity of common fruits, J. Agric. Food Chem. 56 (2008) 8418-8426.

[14] Wan H., Sun H., Yu X., Li Y., Liu D., Development and validation of a caco-2 cell-based quantitative antioxidant activity assay for antioxidants, Food Chem. (2014) (submitted).

[15] Artursson P.,Karlsson J., Correlation between oral-drug absorption in humans and apparent drug permeability coefficients in human intestinal epithelial (caco-2) cells, Biochem. Biophys. Res. Commun. 175 (1991) 880-885.

[16] Liu C.S., Glahn R.P., Liu R.H., Assessment of carotenoid bioavailability of whole foods using a caco-2 cell culture model coupled with an in vitro digestion, J. Agric. Food Chem. 52 (2004) 4330-4337.

[17] Dewanto V., Wu X., Adom K.K., Liu R.H., Thermal processing enhances the nutritional value of tomatoes by increasing total antioxidant activity, J. Agric. Food Chem. 50 (2002) 3010-3014.

[18] Singleton V.L., Orthofer R., Lamuela-Raventós R.M., Analysis of total phenols and other oxidation substrates and antioxidants by means of Folin-Ciocalteu reagent, Method. Enzymol. (1999) 152-178.

[19] Jia Z., Tang M., Wu J., The determination of flavonoid contents in mulberry and their scavenging effects on superoxide radicals, Food Chem. 64 (1999) 555-559.

[20] Huang D.J., Ou B.X., Hampsch-Woodill M., Flanagan J.A., Prior R.L., High-throughput assay of oxygen radical absorbance capacity (orac) using a multichannel liquid handling system coupled with a microplate flourescence reader in 96-well format, J. Agric. Food Chem. 50 (2002) 4437-4444.

[21] Kim D.-O., Jeong S.W., Lee C.Y., Antioxidant capacity of phenolic phytochemicals from various cultivars of plums, Food Chem. 81 (2003) 321-326.

[22] Contessa C., Mellano M.G., Beccaro G.L., Giusiano A., Botta R., Total antioxidant capacity and total phenolic and anthocyanin contents in fruit species grown in northwest Italy, Sci. Hortic. 160 (2013) 351-357.

[23] Chun O.K., Kim D.-O., Smith N., Schroeder D., Han J.T., Lee C.Y., Daily consumption of phenolics and total antioxidant capacity from fruit and vegetables in the american diet, J. Sci. Food Agric. 85 (2005) 1715-1724.

[24] Fu L., Xu B.-T., Xu X.-R., Gan R.-Y., Zhang Y., Xia E.-Q., Li H.-B., Antioxidant capacities and total phenolic contents of 62 fruits, Food Chem. 129 (2011) 345-350.

[25] Isabelle M., Lee B.L., Lim M.T., Koh W.-P., Huang D., Ong C.N., Antioxidant activity and profiles of common fruits in Singapore, Food Chem. 123 (2010) 77-84.

[26] Wu X., Beecher G.R., Holden J.M., Haytowitz D.B., Gebhardt S.E., Prior R.L., Lipophilic and hydrophilic antioxidant capacities of common foods in the United States, J. Agric. Food Chem. 52 (2004) 4026-4037.

[27] Halvorsen B.L., Holte K., Myhrstad M.C., Barikmo I., Hvattum E., Remberg S.F., Wold A.B., Haffner K., Baugerod H., Andersen L.F., Moskaug O., Jacobs D.R., Jr., Blomhoff R., A systematic screening of total antioxidants in dietary plants, J. Nutr. 132 (2002) 461-471.

[28] Vijaya Kumar Reddy C., Sreeramulu D., Raghunath M., Antioxidant activity of fresh and dry fruits commonly consumed in india, Food Res. Int. 43 (2010) 285-288.

[29] Leong L.P., Shui G., An investigation of antioxidant capacity of fruits in singapore markets, Food Chem. 76 (2002) 69-75.

[30] Murcia M.A., Jimenez A.M., Martinez-Tome M., Evaluation of the antioxidant properties of mediterranean and tropical fruits compared with common food additives, J. Food Protect. 64 (2001) 2037-2046.

[31] Almeida M.M.B., de Sousa P.H.M., Arriaga Â.M.C., do Prado G.M., Magalhães C.E.d.C., Maia G.A., de Lemos T.L.G., Bioactive compounds and antioxidant activity of fresh exotic fruits from northeastern brazil, Food Res. Int. 44 (2011) 2155-2159. 